\title{
Optimization of Dump Bench Configuration to Improve Waste Dump Capacity of Narynsukhait Open Pit Coal Mine
}

\author{
Tsedendorj Amarsaikhan, Hideki Shimada, Sugeng Wahyudi, Takashi Sasaoka, \\ Akihiro Hamanaka \\ Department of Earth Resources Engineering, Kyushu University, Fukuoka, Japan \\ Email: wahyudi_sugeng@mine.kyushu-u.ac.jp
}

How to cite this paper: Amarsaikhan, T., Shimada, H., Wahyudi, S., Sasaoka, T. and Hamanaka, A. (2018) Optimization of Dump Bench Configuration to Improve Waste Dump Capacity of Narynsukhait Open Pit Coal Mine. International Journal of Geosciences, 9, 379-396.

https://doi.org/10.4236/ijg.2018.96024

Received: May 29, 2018

Accepted: June 25, 2018

Published: June 28, 2018

Copyright $\odot 2018$ by authors and Scientific Research Publishing Inc. This work is licensed under the Creative Commons Attribution International License (CC BY 4.0).

http://creativecommons.org/licenses/by/4.0/

\begin{abstract}
In next two years, the current waste dump of Narynsukhait coal mine is predicted insufficient to accommodate the overburden as limited of the waste dump capacity. Thus, redesigning waste dump is paramount to increase capacity of the dump in future. This paper describes current condition of waste dump of Narynsukhait coal mine and then discusses the optimization of waste dump geometry by analyzing the effect of different waste dump's bench configuration on slope performance. Optimization of the geometry is carried out by investigating and comparing the performance of geometrical combinations of bench height, bench angles and number of safety berm by means of numerical modeling. The model shows that increasing height of bench is able to induce shear stress in the bench and may initiate bench instable. However, the shear stress can be limited by having safety berm and/or reducing bench angle to satisfy the stability criteria.
\end{abstract}

\section{Keywords}

Waste Dump, Bench Stability, Bench Configuration, Open Pit, Coal Mine

\section{Introduction}

Mining gives highest contribution on Mongolian economic growth; it accounts for $20 \%$ of Mongolian GDP [1]. The Mongolian mining products that given a great contribution to GDP is coal, second largest after copper concentrate. It is not surprisingly when the government projected coal production to grow from year to year to increase the GDP. The government projected coal production increases from $65 \mathrm{Mt}$ on 2015 to $95 \mathrm{Mt}$ on 2020 [1]. 
Narynsukhait, a coal mine which located in the Omnogovi Province, is one of coal companies which have biggest fossil coal reserves in Mongolia with $380 \mathrm{Mt}$ coal deposits that have great progress in regards to coal production. Narynsukhait coal mine has produced $8 \mathrm{Mt}$ of coal on 2015. It is almost three times of their production on 2013, and it has increased over four times when the company just begun their production on 2008. The coal of Narynsukhait coal mine production is expected to more increase to fulfill target of Mongolian coal production.

The problem on Narynsukhait coal mine arises in regards to coal production when they face a fact that volume of their waste dump is predicted not enough to accommodate the overburden in two years. The volume of overburden is projected to be over 35 million cubic meters based on current design of the waste dump. If the volume of overburden waste material continues to increase, it may lead to dump slope vulnerability. It has been reported that over capacity or weight of deposited waste may cause slope loss and slope deformation [2] [3]. In mining industry, stability of waste dump is essential for smooth mining operations and to avoid any slope failure and hazardous accordingly for mining activities [4]. Therefore, a proper design of waste dump should be done in order to preserve the safety of workers and machineries [5]. Currently, in order to accommodate the overburden, Narynsukhait coal mine has three productive waste dumps (Figure 1). These waste dumps have height $20 \mathrm{~m}$ and bench angle around $36^{\circ}$ to $38^{\circ}$.

Considering to aforementioned problem, Narynsukhait coal mine plans to redesign the waste dump to increase the capacity. There are several factors that together contribute to waste dump slope geometry. The most important is bench height and overall slope angle or slope angles of individual bench. This paper presents options to improve the volume of waste dump of Narynsukhait coal mine by improving the bench height. In general, the shape of a waste dump slope is governed largely by the ground conditions under the slope and the shear strength of the mine wastes [6]. Thus, in this study, the improvement has been done by considering potential of deformation of the dump.

\section{Description of Research Area}

\subsection{Geological Characteristics}

The causes of slope failure are categorized as potential causes such as vulnerable geological properties, rainfall and ground cutting [3] [7] [8] [9]. Therefore, the physical and mechanical of the waste dump is identified in addition to diverse geological and hydraulic when stability of a waste dump slope is evaluated.

The Narynsukhait coal mine is situated in the complexly folded, faulted and in places, intensely metamorphosed stratigraphic sequences that host deposits of strategic minerals, oil and gas, and coal. The mining property sits north of an extensive thrust fault system that roughly parallels the Mongolian border [10]. The aerial view of Narysukhait area is given at Figure 2. It is shown in this figure 


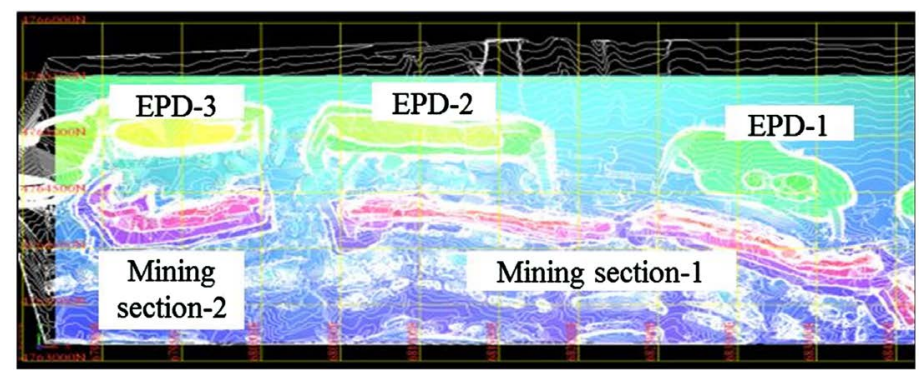

Figure 1. Location and topographic map of the study area (source: Narynsukhait coal mine).

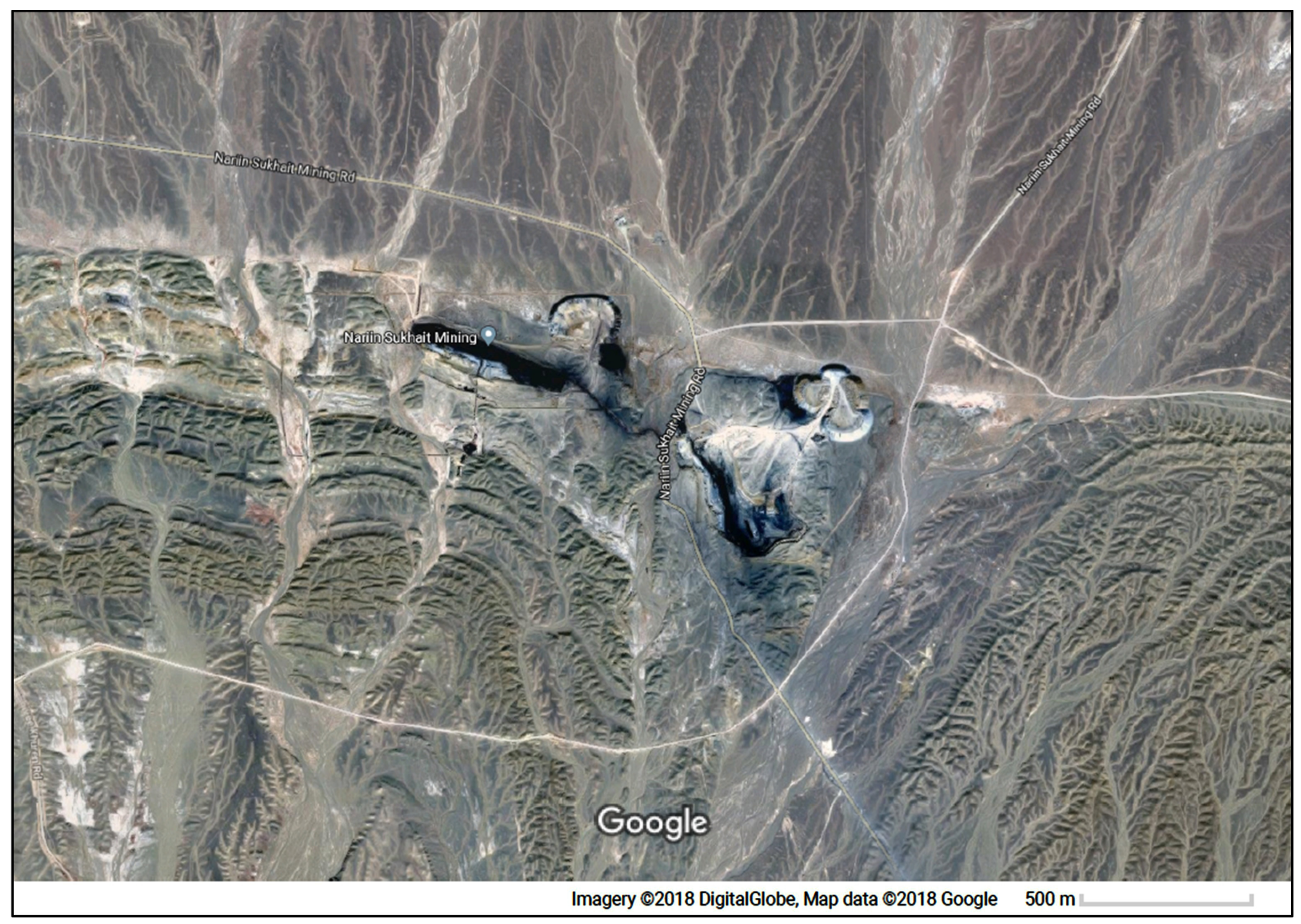

Figure 2. Aerial view of Narysukhait area (source: Google maps).

that the length of the mine is around $1 \mathrm{~km}$ from east to south. The western part of the mining area is hilly, whereas the northern part is flat. As shown in Figure 1 and Figure 2, the waste dump is located at northern part of the open pit which is consisted of simpler geological condition.

\subsection{Dumping Material Characteristics}

The study is situated in MAK field of Narynsukhait coal deposit. This deposit has 35 to $40 \mathrm{~m}$ thickness of coal seam with overburden that consists of shale stone, siltstone, sandstone and conglomerate as shown by stratigraphic column 
of Narynsukahit area in Figure 3 [11]. This stratigraphic column has been proven by core samples' information that drilled in this area. The illustration of core sample is given in Figure 4. Regarding to the overburden material of Narynsukhait coal mine, the material is hauled and dumped at the waste dump without considering to classification of waste rock type. In order to support the study, a series of field monitoring and experiment has been conducted such as particle size distribution, permeability test, moisture content, and geotechnical parameter.

\begin{tabular}{|c|c|c|c|c|c|}
\hline 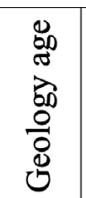 & .气્气ี & $\begin{array}{l}\text { ". } \\
\text { है } \\
\text { है }\end{array}$ & 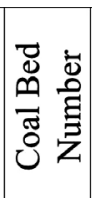 & 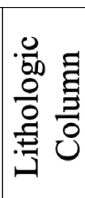 & 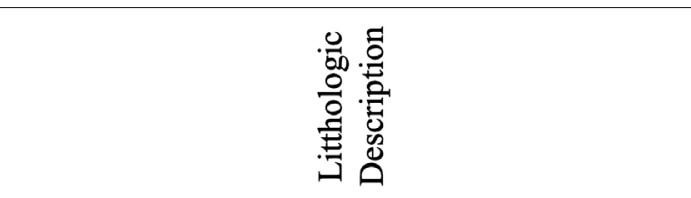 \\
\hline 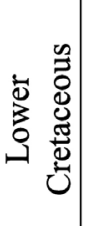 & & 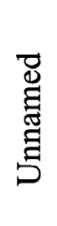 & & 䕥 & $\begin{array}{l}\text { Gray colored, medium to coarse grain sandstone, } \\
\text { interbedded with polymictic conglomerate, tuffs, } \\
\text { and siltstone. } \\
\text { Thickness: } \sim 80 \mathrm{~m}\end{array}$ \\
\hline 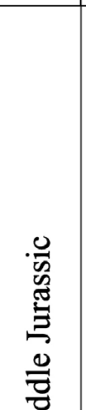 & 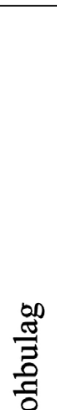 & $\sum$ & $\begin{array}{c}13 \\
12 \\
11 \\
10 \\
9 \\
8 \\
7\end{array}$ & 商 & $\begin{array}{l}\text { Interbedded sequence of dark organic rich } \\
\text { siltstones and mudstones, medium to fine } \\
\text { grained arkosic sandstone and well-sorted } \\
\text { conglomeratic beds with flattened clasts of } \\
\text { silicic volcanic and tuffaceous rocks. } \\
\text { Interspersed coalbeds occur more frequently in } \\
\text { upper part of sequence. } \\
\text { Thickness: } \sim 130 \mathrm{~m}\end{array}$ \\
\hline $\begin{array}{l}\sum_{1}^{1} \\
0 \\
0 \\
0 \\
0 \\
0\end{array}$ & 递 & 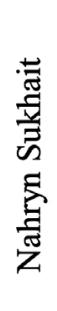 & 5 & & $\begin{array}{l}\text { Well-developed basal conglomerate underlines } \\
\text { thick sequence of organic rich and fossiliferous } \\
\text { siltstone and interbedded, competent medium to } \\
\text { fine grained sandstone. Thickest coal seam } \\
\text { occurs in the lower part of the formation. } \\
\text { Thickness: } \sim 160 \mathrm{~m}\end{array}$ \\
\hline
\end{tabular}

Figure 3. Stratigraphic column of Narynsukahit area [11].

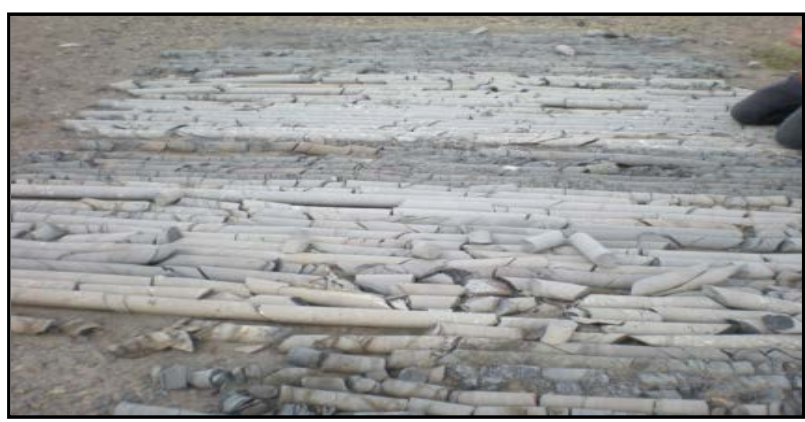

Figure 4. Core sample. 


\subsubsection{Particle Size Distribution}

Particle size distribution can be important in understanding physical properties of a material. It is proven that particle size distribution affects the strength and load-bearing properties of rocks and soils. Moreover, particle size distribution information can be of value in providing initial rough estimates of permeability of a rock mass since particle size influence how fast or slow water moves through it.

Particle size distribution is dependent on the method by which it is determined. The different techniques or even different equipment using the same basic technique are likely to produce different size measurements from the same sample [12]. There is a wide range of measurement methods for particle sizing which has capability over a certain range of particle size. Considering to the advantages that associated with the method such as simple in practice, cheap and ease of interpretation, this study adopted sieve analysis method in determination of particle size distribution.

Considering to particle size usually span several orders of magnitude, a logarithmic scale of particle size and statistical descriptors such as mean and percentile is preferred to descript the distribution. The result of sieving in a logarithmic scale is given in Figure 5. According to Figure 5, the percentile size of the particle size for $X_{20}, X_{50}$ and $x_{80}$ is given $0.08,0.69$ and $4.1 \mathrm{~mm}$, respectively. These particle sizes could be classified by Wentworth grain size classification (Figure 6) as very fine sand, coarse sand and pebble gravel [13]. It is in line with the stratigraphy data of this area that dominated by sandstone. These sizes that are showed by the percentile size certainly affect the permeability, one of the most important parameter in stability, of a rock.

\subsubsection{Permeability and Moisture Content}

The migration of rain water may affect pore-water pressure distribution within the slope. It also may reduce the frictional strength of the dump slopes [14]; accordingly, initiate movement in dump slope along weak plane. The occurrence of such structural problems raises concerns about the stability of waste dump slopes due to rainfall infiltration. Permeability test by means of Hasegawa in situ

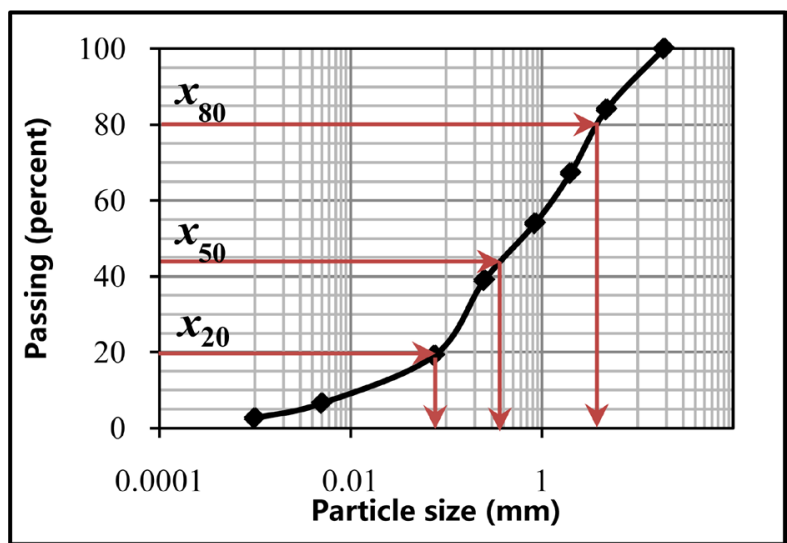

Figure 5. Particle size distribution. 


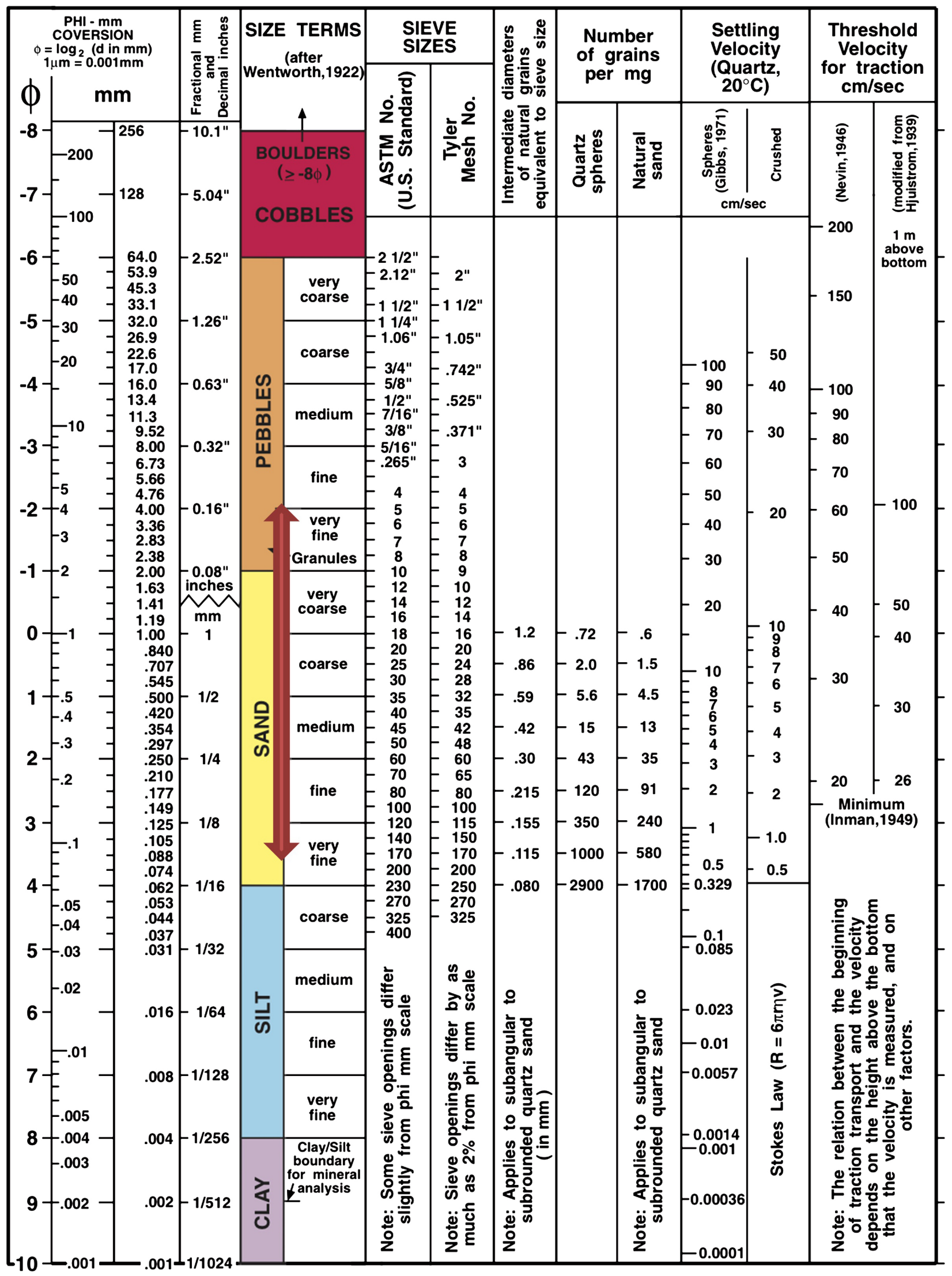

Figure 6. Wentworth grain size chart from USGS Open-File Report 2006-1195. 
permeability has been adopted in order to get information of saturated permeability of the waste rock.

Hasegawa in situ permeability test kit consists of hole cover plate, float plate, scale of $60 \mathrm{~cm}$ and $100 \mathrm{~cm}$, fixed pin and scale guide [15]. Figure 7 illustrates Hasegawa in situ permeability test at the field. While, Figure 8 shows the installation procedure of Hasegawa in situ permeability measurement. A fifteen centimeter diameter of cylindrical hole with depth 20 to $40 \mathrm{~cm}$ was prepared for the tests. Two locations with different characteristics in particle size distribution such as the location which is dominated by larger grained size (i.e. more than or equal to $0.69 \mathrm{~mm}$ ) and location which is dominated by finer grained size (i.e. less than $0.69 \mathrm{~mm}$ ) were chosen for this test. Hereafter, the locations are written as section 1 and section 2 , respectively.

After the preparation has completed that is the float has touched base of hole, amount of water was injected into the hole by siphon pump in a steady stream so that the water pressure break wall of the hole. The water injection was stopped when the water on the level of $100 \mathrm{~mm}\left(h_{1}\right)$ from the hole bottom as shown in Figure 9. After one hour from the $100 \mathrm{~mm}$ leveling, amount of water was injected into the hole and stopped when its level reached $h_{2}$. Level of water inside of hole was recorded two times such as on $20^{\text {th }}$ and $40^{\text {th }}$ minutes from the leveling $h_{2}$ to $h_{3}$ and $h_{4}$ data.

Based on the recorded data, the permeability for the time of $h_{3}$ and $h_{4}$ were calculated by adopting Equation (1) as follows:

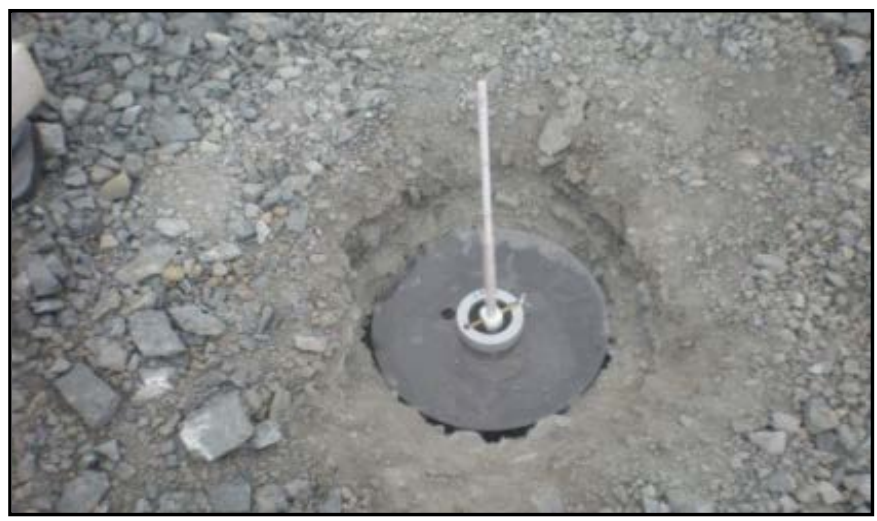

Figure 7. Hasegawa field permeability measurement.
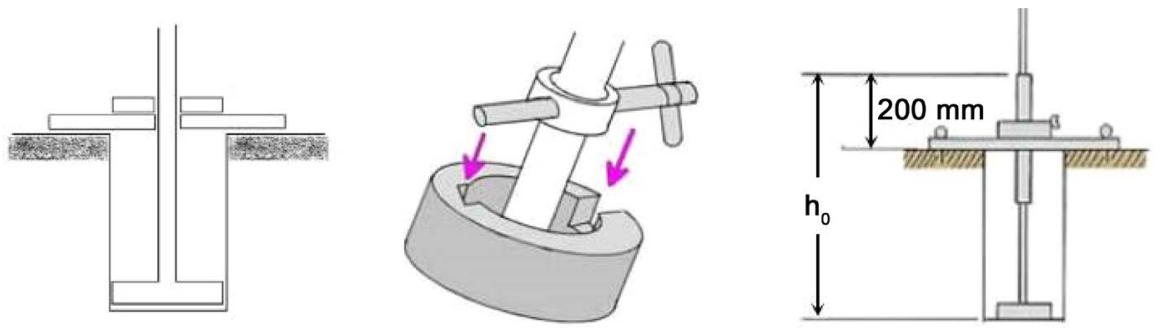

Figure 8. Preparation for measurement: (left) prepare tubular scale with float plate and insert within scale guide bar; (middle) place hole cover plate; (right) tight scale guide bar and set float touch base of hole $\left(h_{0}\right)$ [15]. 


$$
\text { Permeability on } i \text { stage }(\mathrm{mm} / \mathrm{hr})=\frac{\left(h_{i}-h_{i-1}\right)}{\left(t_{i}-t_{i-1}\right) \min } \times 60
$$

where in case of this study $t_{i}-t_{i-1}$ is 20 minutes.

Calculation result of permeability on the waste dump is given in Table 1 . This table shows that the permeability of research area is about $12-180 \mathrm{~mm} /$ hour which is able to be categorized as rapid permeability rate. It could be understood concerning to a waste rock is categorized as unconsolidated rock type which is commonly associated with high pore size. The meteoric water is potential to being infiltrated throughout into the rock and it is likely to affect moisture content of the rock.

Moisture content is one of a major factor in the stability of slope in many unconsolidated rock such as waste dump's material. It is moisture content which changes the rocks from liquid state to plastic state and solid states. Its value controls the shear strength and compressibility of rocks. The increasing moisture content in a rock mass may produce swelling, increasing pore pressure and a decrease in shear strength. Among basic geotechnical parameters, shear strength is of great practical importance. A notable reduction of slope stability is the usual result when the shear strength decreases. As a result, a landslide is possible to occur. Therefore, a series of test has been conducted to confirm the moisture content. Considering to the surface moisture changes with the depth, the moisture content is investigated not only at surface but also below the surface. The samples were taken from the surface up to $600 \mathrm{~mm}$ in depth. Twelve samples were taken from 4 locations of sections 1 and $2 ; 2$ sampling holes for each section.

In this study, the moisture content measurement was performed by oven drying method. In this method, the sample specimen was dried by oven under temperature $60^{\circ} \mathrm{C}$ to $80^{\circ} \mathrm{C}$ till mass of the sample becomes constant. After drying
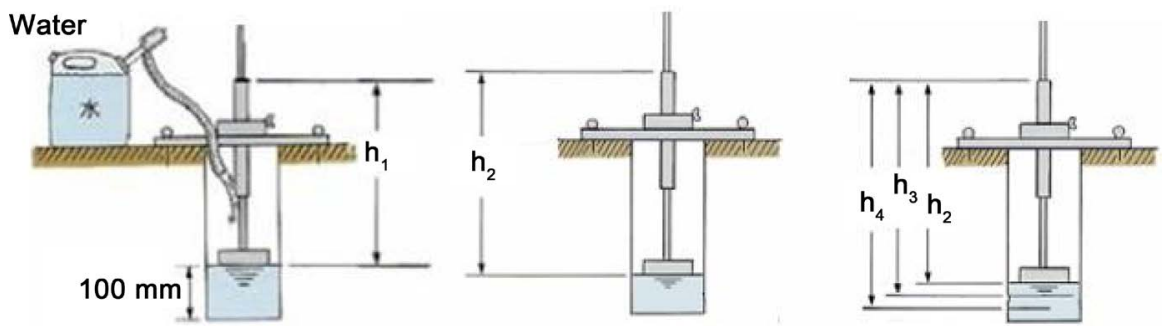

Figure 9. Permeability measurement by means of Hasegawa method [15].

Table 1. Permeability on the waste dump.

\begin{tabular}{cc}
\hline Material & Permeability $(\mathrm{mm} / \mathrm{hr})$ \\
\hline Section 1: dominated by large grained (more than $0.69 \mathrm{~mm})$ & 180 \\
Section 2: dominated by fine grained (less than $0.69 \mathrm{~mm})$ & 150 \\
& 12 \\
\end{tabular}


process has completed, the weight of dried sample together with container and lid was measured and compared with the weight of wet sample with container and lid. Calculation of moisture content is given as follows:

$$
W=\frac{W_{w}}{W_{s}}=\frac{W_{2}-W_{3}}{W_{3}-W_{1}} \times 100
$$

where $W_{1}$ is mass of container with lid, $W_{2}$ is mass of container with lid and wet soil, and $W_{3}$ is mass of container with lid and dry soil. The calculation result of moisture content along the depth is given in Figure 10. It is shown in the figure that moisture content of section 2 is higher than that of section 1 . It may due to finer grained soils has a layer adsorbed water strongly attached to their surface. Unfortunely, this adsorbed layer is not free to move under gravity thus it may cause an obstruction to the flow of water in the pores and hence reduce the permeability. This characteristics of moisture content is in line with the permeability of section 2 that lower than that of section 1.

However, regardless to the different characteristic of moisture content in sections 1 and 2, the figure suggests that the moisture content of the research area is very low. It is possible to occur owing to low rainfall intensity. According to rainfall intensity data that recorded in this area, the rainfall intensity is $0-3 \mathrm{~mm}$ in winter and $30-60 \mathrm{~mm}$ in summer. This intensity can be categorized very low rainfall intensity. Considering to the very low moisture content of waste dump's material, it can be assumed that the moisture content gives low influence on frictional strength of the dump slopes. In other word, the influence of moisture content to slope stability can be neglected.

\subsection{Geotechnical Parameters}

Geotechnical parameters, which are considered in this investigation to determine

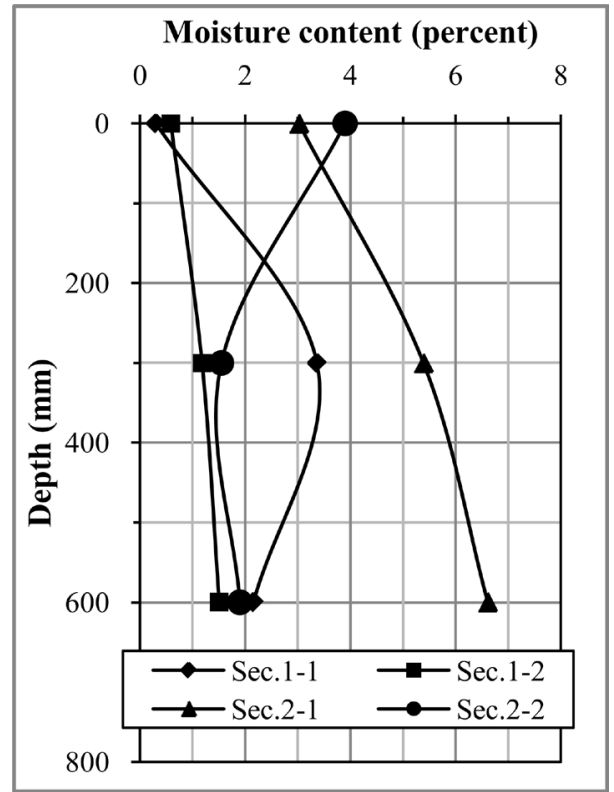

Figure 10. Moisture content. 
optimum combination between height and slope of waste dump like cohesion, angle of internal friction and bulk density after compaction are main factors for stability calculation of a waste dump. The properties of the waste rock dump from a series of laboratory tests are summarized in Table 2.

When the waste rock dump's properties is compared with the overburden's physical properties that given in Table 3, the properties of waste rock dump are much weaker than that of the overburden. It may due to waste rock dump is made up of a mixed rock, unconsolidated rock, and sometimes also contains soil; accordingly the physico-mechanical properties have changed compared to the original materials.

\section{Waste Dump Slope Failure Analysis Method}

Waste dump is possible to failure within the overburden material only or it also possible involves failure of dump foundation. In general, the most general factors affecting stability of any slope are: 1) slope's geometry; 2) material properties; and 3) forces acting on the slope. Finite element methods and limiting equilibrium are the most common method used for slope stability analysis. Both methods are applicable to be used to analyze homogenous and inhomogeneous slopes. However, in a particular case, finite element methods are better than that of limiting equilibrium method in regards to provide more appropriate analysis. The limiting equilibrium methods often face computational difficulties in locating the critical slip surface, and moreover numerical inconsistencies may occur in this case.

Table 2. Waste rock dump's properties.

\begin{tabular}{cc}
\hline Density, $\gamma$ & $2 \mathrm{~g} / \mathrm{cm}^{3}$ \\
Young's modulus, $E$ & $20 \mathrm{MPa}$ \\
Poisson's ratio, $V$ & 0.4 \\
Tensile strength, $T_{s}$ & $0.05 \mathrm{MPa}$ \\
Friction angle, $\varphi$ & $40.6 \mathrm{degree}$ \\
Cohesion, $c$ & $0.0105 \mathrm{MPa}$ \\
\hline
\end{tabular}

Table 3. Overburden's properties.

\begin{tabular}{ccccccc}
\hline Sample & Code & $\begin{array}{c}\text { Density } \\
\left(\mathrm{g} / \mathrm{cm}^{3}\right)\end{array}$ & $\begin{array}{c}\text { UCS } \\
(\mathrm{MPa})\end{array}$ & $\begin{array}{c}\text { Young's } \\
\text { modulus }(\mathrm{GPa})\end{array}$ & $\begin{array}{c}\text { Tension } \\
\text { strength }(\mathrm{MPa})\end{array}$ & $\begin{array}{c}\text { Poission's } \\
\text { ratio }\end{array}$ \\
\hline Sandstone & 1 & 2.48 & 75.92 & 7.2 & 3.74 & 0.32 \\
Conglomerate & 2 & 2.63 & 65.01 & 6.5 & 6.1 & 0.35 \\
Siltstone & 6 & 2.51 & 70.17 & 4.5 & 3.26 & 0.3 \\
Sandstone & $\mathrm{K}-1$ & 2.61 & 85.94 & 7.18 & 7.02 & 0.36 \\
Conglomerate & $\mathrm{K}-2$ & 2.65 & 75.07 & 7.78 & 4.93 & 0.42 \\
Sandstone & $\mathrm{K}-3$ & 2.62 & 85.92 & 5.98 & 5.87 & 0.35 \\
\hline
\end{tabular}


Owing to these inherent limitations of limit equilibrium methods, the finite element method has been increasingly used in slope stability analysis [16] [17] [18] [19]. Despite of the problems that associated with limit equilibrium methods, the finite element methods do not consider assumption about the shape or location of the critical failure surface. The finite element methods also can be easily used with others to calculate stresses, movements, pore pressure in embankments and seepage induced failure as well as for monitoring failure [20]. One more of the advantages of finite element method are that the program can analyze problems in man-made slope, in this case is waste dump slope. In this method, the safety factor is determined using the $\varnothing / c$ reduction approach where the strength parameters $(\tan \varnothing)$ and $(c)$ of the soil are successively reduced until failure of the structure occurs [21]. A slope can be regarded as being stable if the strength reduction factor (SRF) is greater than 1 . Considering to the advantages, finite element method has been adopted to analyze waste dump slope stability in this study.

The analysis was begun by developing a model. The model was created based on geotechnical parameters (Table 2) as well as other information that collected and taken from the laboratory and field test. Moreover, the bench model was created in accordance with the current design; the waste dump is a single bench with high and angle of slope $20 \mathrm{~m}$ and $36^{\circ}$, respectively. The result of bench stability simulation for bench angle $36^{\circ}$ with different bench height is given in Figure 11(a). The SRF of the model is estimated 1.31, which means the slope is stable and has satisfied the stability criteria. However, although the slope is safe, the figure suggests that there is a stress concentration at toe region of the bench. It should be compressive in both radial and circumferential directions [22]. A high stress concentration at toe region indicates that the toe severe high burden pressure. It should be a warning when waste dump is redesigned by increasing the bench height: increase in bench height will be followed by increasing self-load.

According to the results of the simulation when the bench height is increased to $40 \mathrm{~m}$ and $60 \mathrm{~m}$ from $20 \mathrm{~m}$ high, the increasing of height is found initiate significant tensile zones at toe area of the bench due to increasing the self-load of the waste dump. Moreover, it is seen that the shear stress along the slope is also increased. The stress distribution forms like a circular sliding plane shape as shown in Figure 11(b) and Figure 11(c). It seems like that the waste dump slope suffer high deformation due to increasing self-load of the waste dump.

In regards to slope stability, the simulation result shows that the SRF reduces with increasing the bench height from 1.31 for bench height $20 \mathrm{~m}$ to 0.86 and 0.85 for bench height 40 and $60 \mathrm{~m}$, respectively. It means that a circular sliding plane is highly possible to occur on bench in height 40 and $60 \mathrm{~m}$ since the bench strength cannot support the gravity loading. Based on these result, it was considered that maximum high of the bench may not exceed $20 \mathrm{~m}$.

In this study, in order to reduce stress on the bench, berm technique is adopted when the height is more than $20 \mathrm{~m}$ high to satisfy the stability criteria. For a 


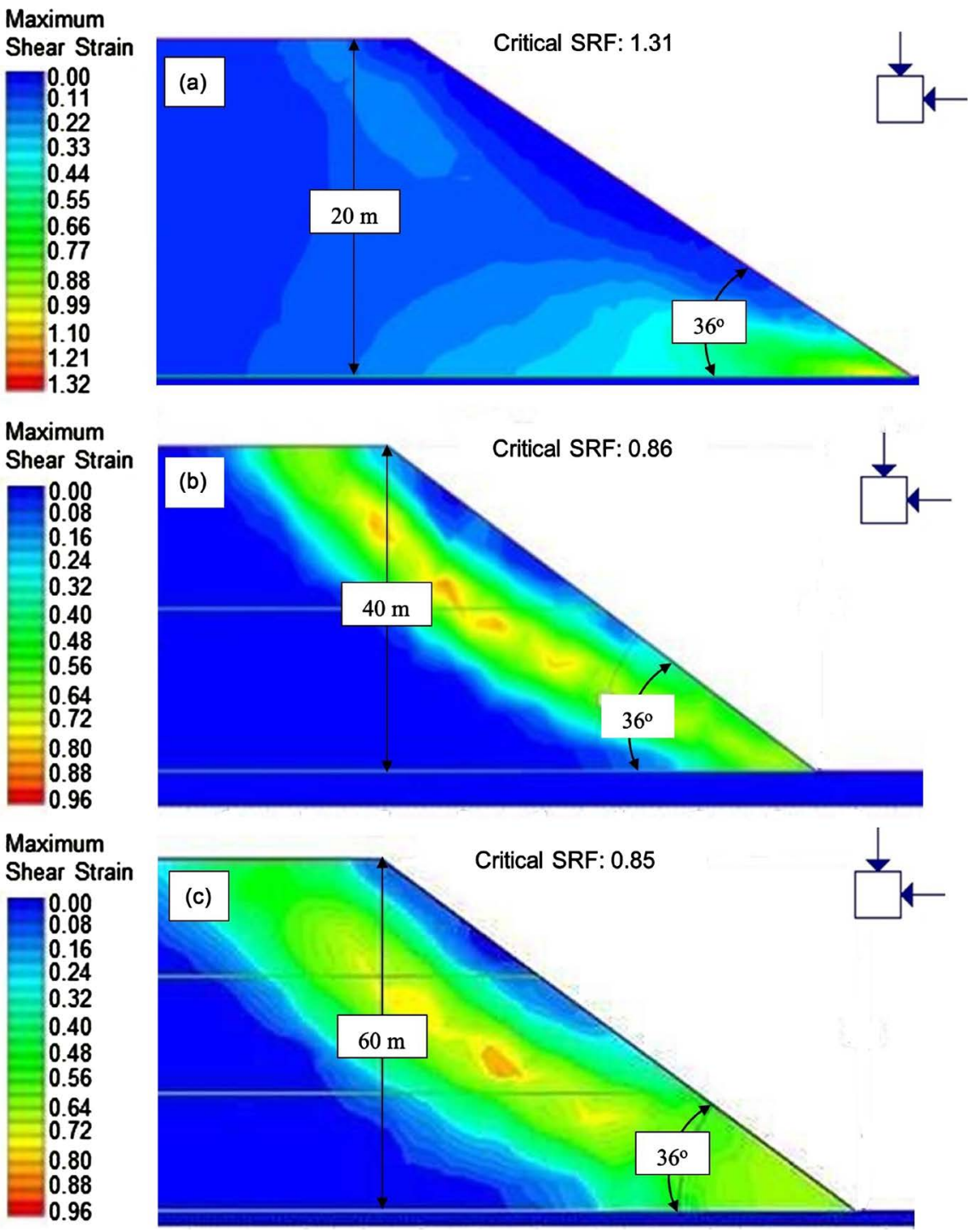

Figure 11 . Result of bench stability simulation for bench angle $36^{\circ}$ with different bench height.

bench which has total height more than $20 \mathrm{~m}$, a $10 \mathrm{~m}$ wide safety berm is introduced for every $20 \mathrm{~m}$ high single bench. The selection of the width of safety berm is, however, most often a function of the equipment size.

\section{Result and Discussion}

According to the simulation result, it has been found that the probability of a large-scale slope failure is high as increasing the bench height. The shape potential sliding surface was defined as the circular type based on the simulation analysis. The location of shear stress below the crest of waste dump was considered as the starting point of sliding surface. In this study, having safety berm is intended to reduce gravity loading, and reduce the shear stress accordingly, by limiting the single bench height that is not more than $20 \mathrm{~m}$. The consequence of having a safety berm is a decreasing of overall slope angle of the bench. 


\subsection{Effect of Having $10 \mathrm{~m}$ Width of Safety Berm}

A ten meter width of safety berm has been chosen not only to fit the bench angle but also designed to be capable to catching the volume of failed material from the bench faces above thus able to reduce the number of rocks that can continue to further fall onto the bench below. Other consideration for safety berms geometry is equipment size.

The simulation result of slope stability of a 40 and $60 \mathrm{~m}$ high of bench with a $10 \mathrm{~m}$ wide of safety berm is given in Figure 12(a) and Figure 12(b). These figures show that owing to having a safety berm, the overall angle slope reduces to $32^{\circ}$ and $31^{\circ}$ for bench height 40 and $60 \mathrm{~m}$, respectively. Figure 12 (a) and Figure 12 (b) are clearly showing that the high shear stress is concentrated at below the crest region, having continuous to toe region of the bench. The simulation result suggests that the $40 \mathrm{~m}$ bench height is in critical point in regards to slope failure; the SRF is given 1.02, whereas the $60 \mathrm{~m}$ bench height is failure which it is indicated by the SRF 0.97 .

Regardless to the benches that are in a critical failure point and/or have not satisfied yet the stability criteria, the shear stress is reduced by having safety berm on the bench. The SRF is increased from 0.86 to 1.02 and 0.85 to 0.97 for bench height 40 and $60 \mathrm{~m}$, respectively. Different with a bench without safety berm which the high tensile stress is concentrated in the toe region and shear stress is found along the slope when the height of bench is increased from $20 \mathrm{~m}$ to 40 and $60 \mathrm{~m}$, for the bench with having safety berm, high stress is found

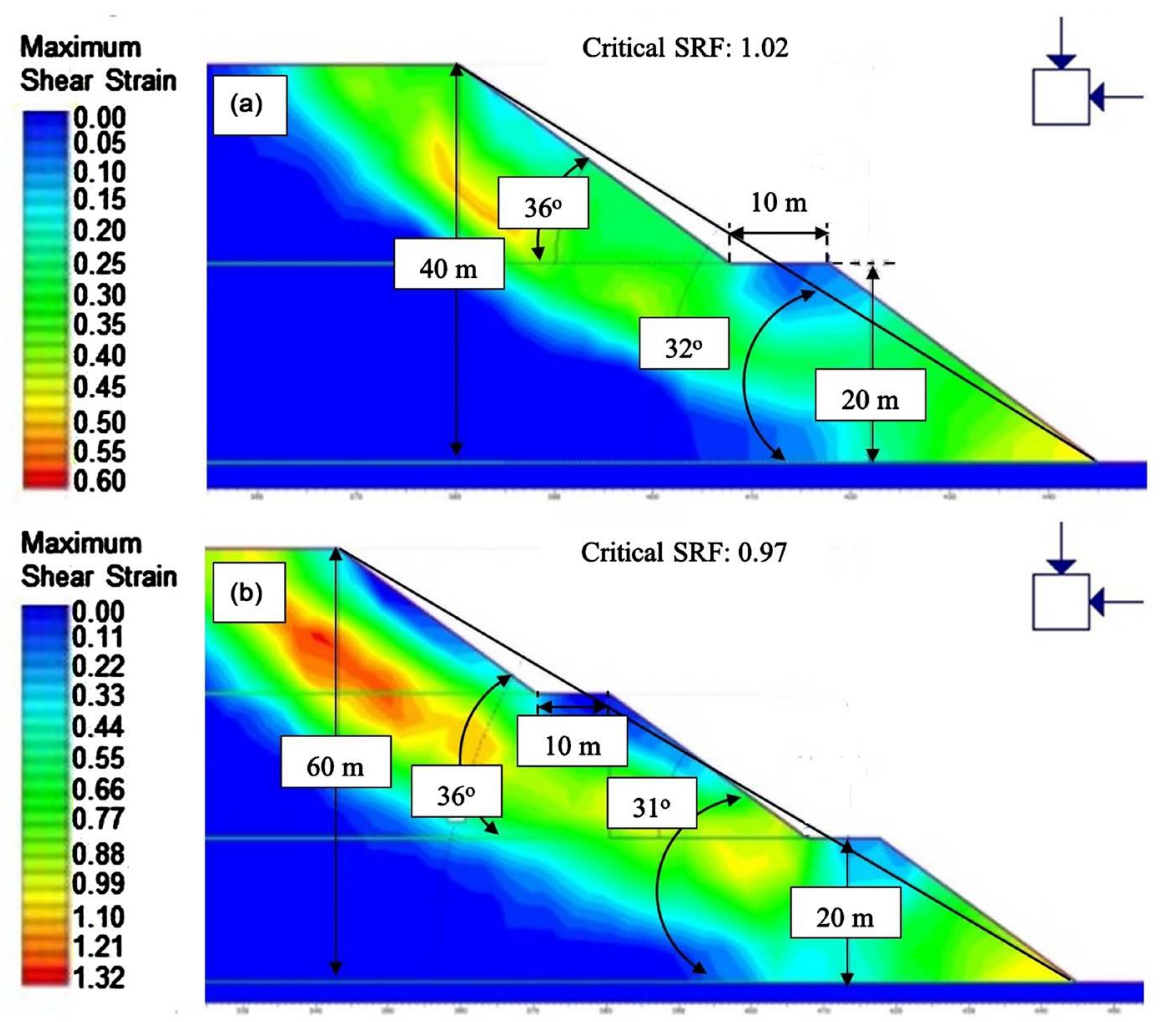

Figure 12. Result of bench stability simulation for bench having safety berm. 
concentrated only in crest region of the bench. This severe stress may be initiated by gravity loading of the waste dump. In order to reduce the stress at crest area, the bench angle is reduced.

\subsection{Effect of Reducing Bench Angle}

Considering to having berm is not enough to guide the slope satisfy the stability criteria, decreasing overall slope was considered to achieve better stability of the slope. In this study, the angle of single slope was decreased 3 degrees i.e. from $36^{\circ}$ to $33^{\circ}$; accordingly the overall angle of slope of $40 \mathrm{~m}$ bench height and $60 \mathrm{~m}$ bench height is decreased to $29^{\circ}$ and $28^{\circ}$, respectively. The simulation result is described in Figure 13(a) and Figure 13(b).

It is shown in Figure 13(a) and Figure 13(b) that the slope is stable for a 40 $\mathrm{m}$ bench height with single safety berm and a $60 \mathrm{~m}$ bench height with two safety berms constructed in it, even though toe of benches suffer high stress. The SRF shows 1.1 and 1.07 for $40 \mathrm{~m}$ bench height and $60 \mathrm{~m}$ bench height, respectively. Moreover, no significant tensile stresses occur for a $33^{\circ}$ slope is found. The occurrence of zones of tensile stress is relatively limited.

\subsection{Optimization of Bench Configuration}

Figure 12(a) and Figure 12(b) show that very large shear stress zones are generated along the slopes when the bench height is increased even though the

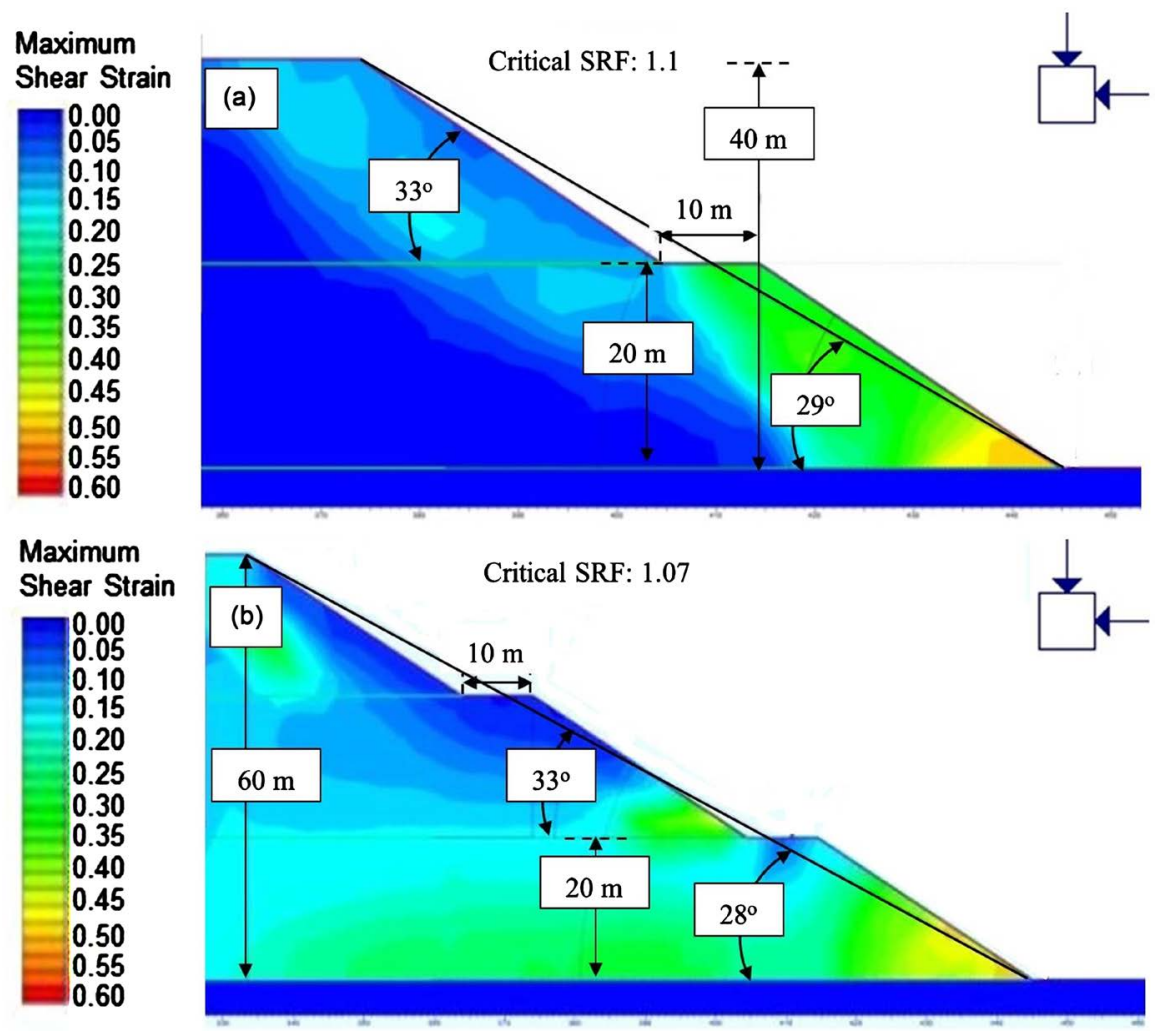

Figure 13. Result of bench stability simulation for bench angle $33^{\circ}$ with different bench height. 
bench has already had safety berm. Meanwhile, when the bench angle is changed to $33^{\circ}$ from the original angle $36^{\circ}$, the shear stress zones are reduced. Based on these simulation results, it is noted that the bench configuration have a significant influence of the occurrence of shear stress.

Considering to bench design for $60 \mathrm{~m}$ in height with 2 safety berms constructed in it is satisfy stability criteria, the simulation is continued by increasing the height up to 80 and $100 \mathrm{~m}$. Accordingly, number of safety berm increases to 3 and 4 for $80 \mathrm{~m}$ bench height and $100 \mathrm{~m}$ bench height, respectively. The simulation result is given in Figure 14 and Figure 15.

Figure 14 and Figure 15 suggest that the slope is stable for the $80 \mathrm{~m}$ bench height. However, the slope becomes unstable when the bench is increased to 100 $\mathrm{m}$ in height. Figure 14 shows strong line of circular sliding plane. However, the resisting force for failure is still stronger than that of driving force. It is indicated by SRF value which is more than one. On the other hand, Figure 15 is unstable slope: the SRF is less than one.

Figure 15 illustrates the shear stress trajectories around a $100 \mathrm{~m}$ bench height. It is likely that fracture surface will develop behind the bench. In the toe region, the tensile stress is generated rapidly and the fracture orientations will correspondingly follow these orientations. Moreover, there is likely to be some time dependency in the development of fractures. Since the size of waste dump

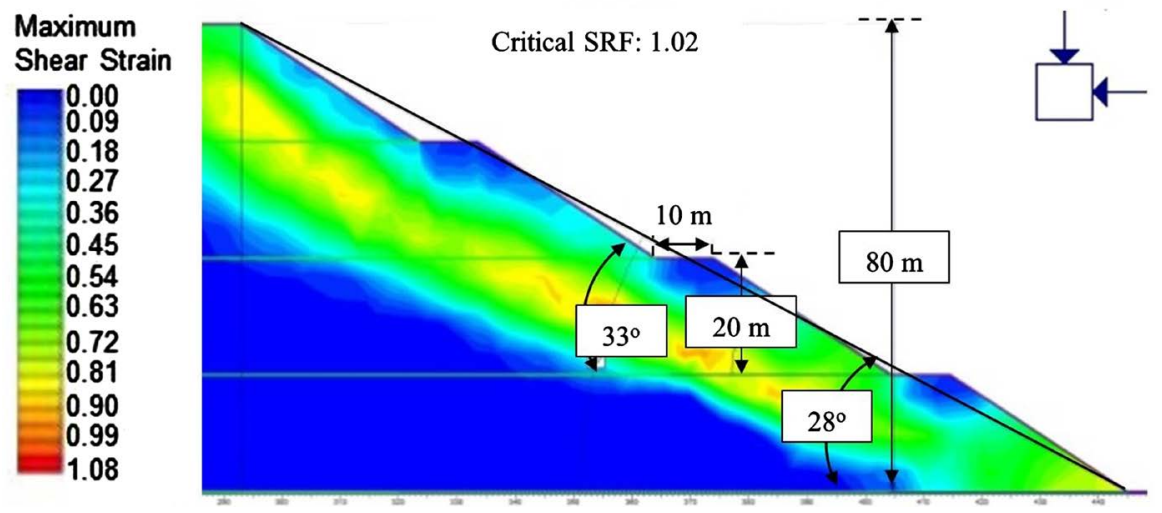

Figure 14. Slope design height $80 \mathrm{~m}$ with 3 safety berms.

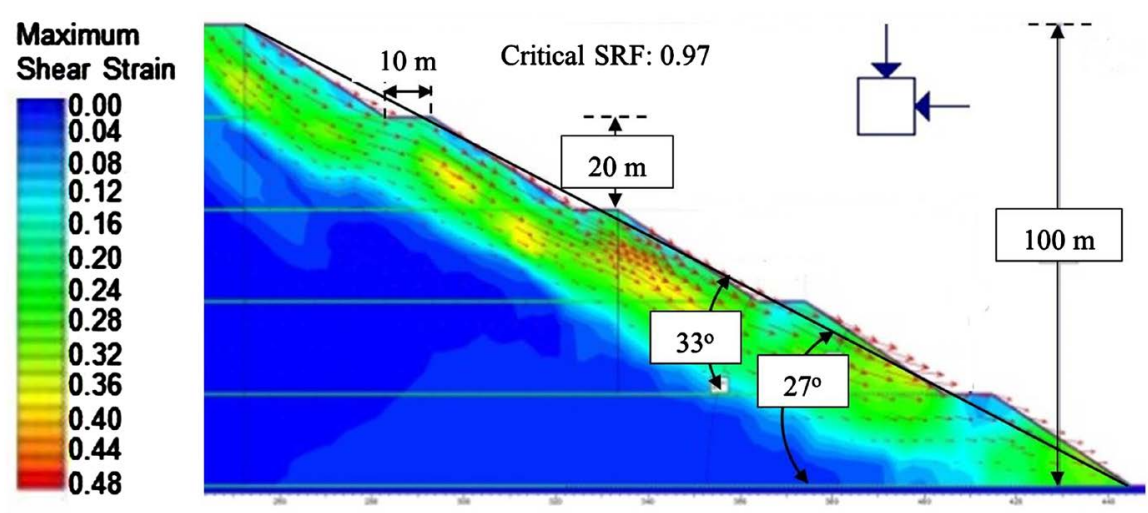

Figure 15. Slope design height $100 \mathrm{~m}$ with 4 safety berms. 
increases slowly, there is an abundance of time for the stress around the dump to readjust and to interact with waste material, promoting the development of facture. Such behavior may cause overall slope failure, or may initiate failure, which may then be driven to overall slope failure.

Based on the above discussion, it is paramount to create a guideline for establishing a bench configuration that satisfies the stability criteria. Figure 16 resumes a stable bench for different bench configuration. It is shown in Figure 16 that safety berm and bench angle play important role in bench stability. The figure shows, in general, that the SRF decreases with increasing the bench height. However, the SRF can be reduced by having safety berm on the bench as well as reducing the bench angle. When the bench height is increased, the self-load of the waste dump is also increased. It induces high shear stress along the bench; moreover it may initiate bench failure. By having the safety berm and reducing the bench angle, the self-load of the waste dump can be reduced.

\section{Conclusions}

In the open pit coal mine, providing a proper waste dump is crucial to mine's successful operation. The improper waste dump results instability issues which may affect safety and production of the mine. In order to improve the capacity of the waste dump by increasing the bench height, a study must be done in regards to analyze performances of a variety of different configurations for bench geometry such as bench height and angle to satisfy the stability criteria. The results of the simulation and analysis of the waste dump slope stability can be summarized as follows:

- Considering to friction angle of waste dump's material, in order to avoid bench failure, it is suggested to design the bench angle do not more than $36^{\circ}$.

- Relatively limited shear stress zones occur behind crest of the bench for a 20 $\mathrm{m}$ bench height.

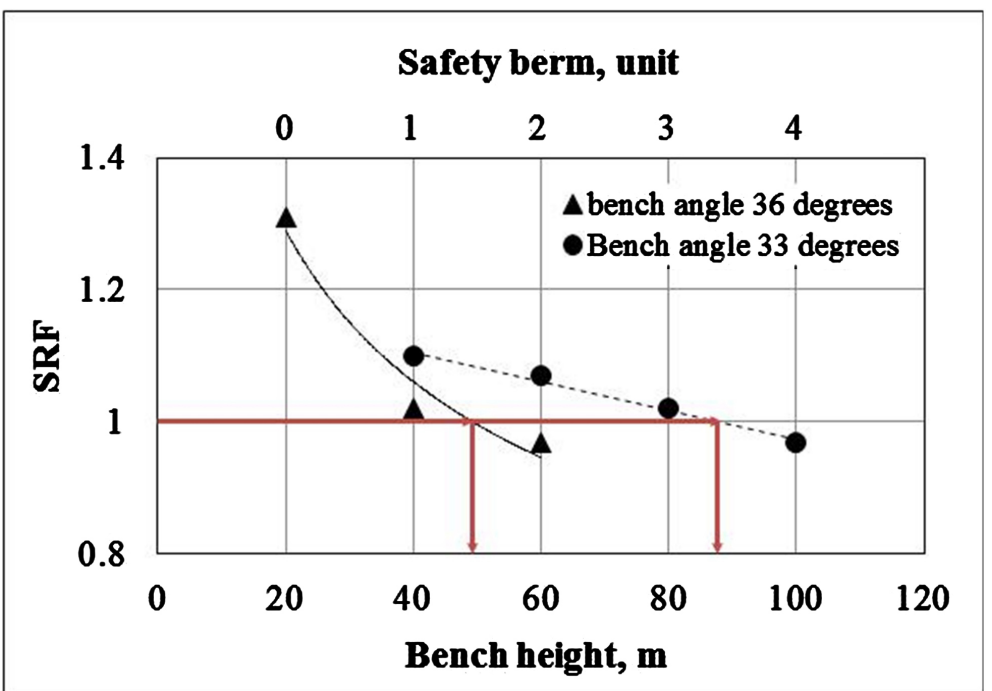

Figure 16. Stable bench configuration for different bench height. 
- Change in bench height has a major impact on stability consideration; the magnitude of shear stress increases with the bench height of the dump. According to the results of the simulation, the slope movement initiated at the crest of the waste dump and the shape of slope failure seemed to be a circular sliding plane due to gravity loading of the waste dump.

- Having $10 \mathrm{~m}$ of safety berm for every $20 \mathrm{~m}$ in height of single bench and reducing bench angle up to 3 degrees can play important role on improving the SRF and reducing the shear stress along the slope.

- Considering to the rock properties of the overburden, the maximum high of the bench to satisfy the stability criteria is $80 \mathrm{~m}$ with three 10 -m-wide safety berms.

- Besides able to reduce shear stress in the bench, a safety berms is also able to reduce the number of rocks that can continue to fall further that put safety of personal and equipment at risk.

\section{References}

[1] National Statistics Office of Mongolia (2017). http://www.en.nso.mn/index.php

[2] Scott, M.D, Lo, R.C. and Thavaraj, T. (2007) Use of Instrumentation to Safeguard Stability of a Tailing Dam. Proceedings of the 7 th International Symposium on Field Measurements in Geomechanics (FMGM), Boston, 692-704. https://doi.org/10.1061/40940(307)56

[3] Cho, Y.C. and Song, Y.S. (2014) Deformation Measurements and a Stability Analysis of the Slope at a Coal Mine Waste Dump. Ecological Engineering, 68, 189-199. https://doi.org/10.1016/j.ecoleng.2014.03.005

[4] Poulsen, B., Khanal, M., Rao, A.M., Adhikary, D. and Balusu, R. (2014) Mine Overbuden Dump Failure: A Case Study. Geotechnical and Geological Engineering, 32, 297-309. https://doi.org/10.1007/s10706-013-9714-7

[5] Hancock, G.R. and Turley, E. (2006) Evaluation of Proposed Waste Rock Dump Designs Using the SIVERIA Erosion Model. Environmental Geology, 49, 765-779. https://doi.org/10.1007/s00254-005-0127-7

[6] Gens, A. and Alonso, E.E. (2006) Aznalcollar Dam Failure. Part 2: Stability Condition and Failure Mechanism. Geotechnique, 56, 185-201.

https://doi.org/10.1680/geot.2006.56.3.185

[7] Rocscience Inc. (2001) Application of the Finite Element Method to Slope Stability, Toronto.

[8] Bishop, A.W. (1955) The Use of the Slip Circle in the Stability Analysis of Earth Slopes. Geotechnique, 5, 7-17. https://doi.org/10.1680/geot.1955.5.1.7

[9] Hoek, E. (1970) Estimating the Stability of Excavated Slopes in Opencast Mines. Institution of Mining and Metallurgy, A105, A132.

[10] Fall, H. (1987) Geotechnical Developments. DSI Slope of the Stability and Retaining Structures Seminar, Samsun.

[11] Hendrix, M.S., Graham, S.A., Amory, J.Y. and Badarch, G. (1996) Noyol Uul Syncline, Southern Mongolia: Lower Mesozoic Sedimentary Record of the Tectonic Amalgamation of Central Asia. GSA Bulletin, 108, 1256-1274. https://doi.org/10.1130/0016-7606(1996)108<1256:NUSSML >2.3.CO;2

[12] U.S. Environmental Protection Agency (2013) Pre-Feasibility Study for Coal Mine 
Methane Recovery and Utilization at Naryn Sukahit Mine.

http://www.ravenridge.com/wp-content/uploads/Mongolia_-Naryn-Sukhait-Prefeas ibility-Study_FINAL.pdf

[13] Mingard, K., Morrell, R., Jackson, P., Lawson, S., Patel, S. and Buxton, R. (2009) Good Practice Guide for Improving the Consistency of Particle Size Measurement. A National Measurement Good Practice Guide 111. http://publications.npl.co.uk/npl_web/pdf/mgpg111.pdf

[14] USGS Open-File Report 2006-1195. Wentworth Grain Size Chart. https://pubs.usgs.gov/of/2006/1195/htmldocs/images/chart.pdf

[15] Daitou Techno Green (2009) Hasegawa in Situ Permeability Tester. Operating Manual V.3.1. http://www.daitoutg.co.jp/prd/pdf/tousui0703.pdf

[16] Verma, D., Kainthola, A., Gupte, S.S. and Singh, T.N. (2013) A Finite Element Approach of Stability Analysis of Internal Dump Slope in Wardha Valley Coal Field, India, Maharashtra. American Journal of Mining and Metallurgy, 1, 1-6.

[17] Hughes, R. (1987) The Finite Element Method: Linear Static and Dynamic Finite Element Analysis. Prentice-Hall, Englewood Cliffs.

[18] Strang, G. and Fix, J. (1973) An Analysis of the Finite Element Method. Prentice-Hall, Englewood Cliffs.

[19] Clough, R. and Woodward, R. (1967) Analysis of Embankment Stresses and Deformations. Journal of Soil Mechanics and Foundations Division, 4, 529-549.

[20] Zienkiewicz, C. and Taylor, L. (1989) The Finite Element Method. 4th Edition, McGraw-Hill, New York, 1.

[21] Hammouri, N.A., Malkawi, A.I.H. and Yamin, M.M.A. (2008) Stability Analysis of Slopes Using the Finite Element Method and Limiting Equilibrium Approach. Bulletin of Engineering Geology and the Environment, 67, 471-478. https://doi.org/10.1007/s10064-008-0156-Z

[22] Stacey, T.R., Xianbin, Y., Amstrong, R. and Keyter, G.J. (2003) New Slope Stability Consideration for Deep Open Pit Mines. The Journal of the South African Institute of Mining and Metallurgy, 103, 373-389. 